DOI: $\underline{\text { https://doi.org/10.31933/jemsi.v2i5 }}$

Received: 15 April 2021, Revised: 15 Mei 2021, Publish: 25 Juni 2021

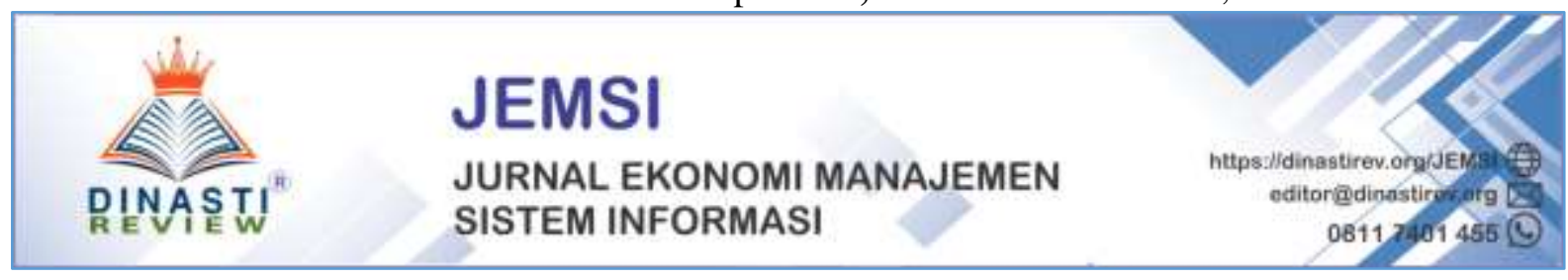

\title{
DETERMINASI LIKUIDITAS DAN SUKU BUNGA: ANALISIS NILAI PERUSAHAAN DAN RETURN SAHAM (LITERATURE REVIEW MANAJEMEN KEUANGAN)
}

\section{Agustinus Hendi Priyambudi ${ }^{1}$ \\ ${ }^{1)}$ Mahasiswa Program Magister Manajemen, Universitas Mercubuana Jakarta, email: hendi.agustinus@gmail.com}

\section{Corresponding author: Agustinus Hendi Priyambudi ${ }^{1}$}

Abstrak: Riset terdahulu atau riset yang relevan sangat penting dalam suatu riset atau artikel ilmiah. Riset terdahulu atau riset yang relevan berfungsi untuk memperkuat teori dan penomena hubungan atau pengaruh antar variable. Artikel ini mereview Determinasi Likuiditas dan Suku Bunga: Analis Suku Bunga dan Return Saham (Literature Review Manajemen Keuangan). Hasil dari library risearch ini adalah bahwa: 1) Nilai Perusahaan berpengaruh terhadap Likuiditas; 2) Return Saham berpengaruh terhadap Likuiditas; 3) Nilai Perusahaan berpengaruh terhadap Suku Bunga; 4) Return Saham berpengaruh terhadap Suku Bunga; dan 5) Likuiditas berpengaruh terhadap Suku Bunga.

Kata Kunci: Likuiditas, Suku Bunga, Nilai Perusahaan dan Return Saham.

\section{PENDAHULUAN}

\section{Latar Belakang Masalah.}

Setiap mahasiswa baik Strata 1, Strata 2 dan Strata 3, di wajibkan untuk melakukan riset dalam bentuk skripsi, tesis dan disertasi. Begitu juga bagi dosen, peneliti dan tenaga fungsional lainya aktif melakukan riset dan membuat artikel ilmiah untuk di publikasi pada jurnal-jurnal ilmiah.

Berdasarkan pengalaman empirik semua mahasiswa dan dosen muda juga peneliti lainnya, memeroleh kesulitan untuk mencari artikel pendukung dalam riset sebagai penelitian terdahulu atau sebagai penelitian yang relevan. Artikel sebagai peneliti yang relevan di 
perlukan untuk memperkuat teoti yang di teliti, untuk melihat hubungan antar variable dan membangun hipotesis, juga sangat diperlukan pada bagian pembahasan hasil penelitian.

Artikel ini membahas pengaruh nilai perusahaan dan return saham terhadap likuiditas dan akibatnya terhadap suku bunga, (Suatu Studi Literatur Manajemen Keuangan). Tentu tidak banyak faktor yang mempengaruhi Motivasi Kerja dan Kinerja Karyawan pada artikel ini, ini hanya sebagian kecil saja yang akan di kaji dan di review.

Secara rinci tujuan dari penulisan "Literature Review Paper" ini adalah mengetahui pengaruh atau hubungan antara variabel exogen nilai perusahaan dan return saham terhadap variabel endogen likuiditas dan suku bunga.

1) Pengaruh atau hubungan nilai perusahaan terhadap likuiditas.

2) Pengaruh atau hubungan return saham terhadap likuiditas.

3) Pengaruh atau hubungan nilai perusahaan terhadap suku bunga.

4) Pengaruh atau hubungan return saham terhadap suku bunga.

5) Pengaruh atau hubungan likuiditas terhadap suku bunga.

\section{KAJIAN TEORI}

\section{Likuiditas}

Rasio likuiditas (liquidity ratio) merupakan rasio yang memiliki tujuan untuk mengukur apakah perusahaan memiliki kemampuan untuk membayar hutang dalam jangka pendek (Sugiono \& Untung, 2016). Likuiditas dapat diukur dengan current ratio untuk mengetahui sejauh mana aktiva lancar yang dipunyai oleh perusahaan bisa digunakan untuk membayar hutang lancar yang harus segera dibayar (Sugiono \& Untung, 2016). Menurut Fahmi (2016) memiliki kegunaan untuk mengukur kemampuan suatu perusahaan memiliki kebutuhan utang saat jatuh tempo menggunakan rasio lancar (current ratio).

Menurut Kasmir (2014), likuiditas adalah rasio yang sudah mengukur kemampuan perusahaan dalam memenuhi kewajibannya pada saat jatuh tempo, baik dari pihak luar maupun perusahaan yang ada didalam.

Menurut Lukman Syamsuddin (2009), Likuiditas adalah indikator tentang kemampuan perusahaan dalam membayar kewajiban finansial jangka pendek pada jatuh tempo dengan memakai aktiva lancarnya. Likuiditas dengan kondisi kesemua, keuangan perusahaan namun juga berkaitan dengan kemampuannya untuk merubah aktiva lancar menjadi uang kas.

Likuiditas bisa didefinisikan untuk tingkat kemampuan suatu perusahaan dapat membayar hutang-hutang yang sudah ditetapkan jatuh tempo (Kasmir, 2013). Menurut 
Mamduh (2004), likuiditas diartikan sebagai kemampuan suatu perusahaan memenuhi kewajiban keuangan dalam jangka pendek atau yang harus dibayar. Menurut Titman et al (2014), likuiditas merupakan "the speed with which the asset can be converted into cash without loss of value. Likuiditas perusahaan juga dapat diukur dengan rasio lancar (current ratio). Rasio lancar juga bisa ditunjukkan oleh kemampuan perusahaan dalam membayar hutang lancar menggunakan aktiva lancar yang dimiliki (Sudana,2009: 24). Likuiditas adalah kewajiban dalam finansial untuk jangka pendek yang tepat pada waktunya (Subramanyan dan Wild, 2009:223). Jika semakin tinggi tingkat likuiditas akan perusahaan kepastiannya untuk dijadikan uang tunai.

\section{Suku Bunga}

Suku bunga merupakan harga atau jumlah biaya yang telah dikeluarkan untuk memperoleh pinjaman tersebut (Mishkin, 2008). Menurut Khalwaty (2010) adanya tinggi suku bunga membuat investor mengalihkan dananya untuk menginvestasikan di bank dari pada menginvestasikan pada sektor produksi atau industri karena mempunyai tingkat risiko yang lebih besar. Tingkat suku bunga menurut Boediono (2014:76) merupakan semua harga dari penggunaan dana serta investasi (loanable funds). Tingkat suku bunga ialah salah satu indikator yang bisa menentukan apakah seseorang yang bisa melakukan menabung atau investasi. Untuk membandingkan akan tingkat keuntungan serta resiko pada pasar modal dengan tingkat suku bunga yang sudah ditawarkan ke sektor keuangan, investor bisa memutuskan bentuk investasi yang memiliki kemampuan akan hasil dari keuntungan yang lebih optimal. Tingkat suku bunga dalam sektor keuangan yang biasa digunakan sebagai panduan investor disebut tingkat suku bunga bebas resiko (risk free), adalah meliputi tingkat suku bunga bank sentral serta tingkat suku bunga deposito.

Pengertian suku bunga menurut Sunariyah (2013:80) adalah "harga dari pinjaman. Suku bunga dinyatakan sebagai persentase uang pokok per unit waktu. Bunga adalah suatu ukuran harga sumber daya yang dipakai oleh debitur yang memiliki kewajiban untuk membayar kepada kreditur.

Di Indonesia tingkat suku bunga Bank sentral di proxykan tingkat suku bunga Sertifikat Bank Indonesia atau SBI (Husnan, 2003:21). Menurut Kieso, Weygandt, Warfield (2011:289) "Interest rate is a precentage of outstanding principal". Sedangkan Brigham dan Houston (2010:234-235) mengemukkan "Tingkat bunga yang sudah dinyatakan (nominal) suatu efek utang $r$, terdiri atas tingkat bunga nyata bebas resiko, ditambah beberapa premi yang sudah dicerminkan inflasi, kemungkinan akan dipasarkan, risiko efek. 
Suku bunga adalah faktor penting yang bisa mempengaruhi perekonomian suatu negara sehingga berpengaruh kuat terhadap pasar modal (Manurung, 2016). Dalam keadaan suku bunga dari bank bagi deposito meningkat, maka investor akan cenderung mengubah keputusan berinvestasinya dari saham ke bank. Hal ini bisa menyebabkan turunya permintaan akan saham dan menurunnya nilai saham serta berakibat menurunnya nilai perusahaan. Suku bunga serta sebuah prakiraan nilainya dimasa depan adalah salah satu masukan yang terpenting dalam sebuah keputusan investasi (Bodie et al.., 2008:180).

Tingkat suku bunga serta tinggi untuk meningkatkan biaya modal serta tanggung perusahaan serta juga akan menyebabkan return yang kemudian investor dari suatu investasi akan meningkat (Wismantara, 2017).

Penelitian yang dilakukan Oshaibat (2016) bahwa tingkat suku bunga berpengaruh negatif terhadap return saham, penelitian yang sama juga dilakukan oleh Quadir (2012), Olweny \& Omondi (2011), Latha et al. (2016), Butt et al.. (2010), Bilal et al.. (2012), Kandir (2008), Sadikin (2010), Setyaningrum (2016), Oktiar (2014), Saputra \& Dharmadiaksa (2016), Faoriko (2013), Nidianti (2013) dan Adeputra \& Wijaya (2016). Sebaliknya, menurut Sudarsono \& Sudiyanto (2016), Karim (2015), dan Buana (2014) bahwa suku bunga berpengaruh positif terhadap return saham. Sedangkan menurut Kristanto (2016) dan Dwita, \& Rahmidani (2012) suku bunga tidak berpengaruh terhadap return saham.

\section{Nilai Perusahaan}

Margareta (2011) menjelaskan bahwa bagi perusahaan yang sudah go-publik nilai perusahaan yang tercermin di setiap harga pasar saham perusahaan, sedangkan bagi perusahaan yang belum go public nilai perusahaan yang terealisasi namun perusahaan akan dijual yang dapat total aktiva prospek perusahaan, risiko usaha serta lain-lain, lingkungan usaha.

Sementara menurut Husnan \& Pudjiastuti (2015) bahwa "nilai perusahaan adalah harga yang tersedia kemudian dibayar oleh calon pembeli jika perusahaan tersebut dijual". Menurut Ernawati dan Widyawati (2015:3-4) salah satu hal yang dipertimbangkan oleh investor dalam melakukan investasi adalah nilai perusahaan dimana investor tersebut akan menanamkan modal. Hal yang sama dikemukakan oleh Pertiwi, dkk (2016) bahwa nilai perusahaan yang tinggi akan membuat pasar percaya tidak hanya pada kinerja perusahaan saat ini namun juga pada prospek perusahaan dimasa depan. Kemakmuran pemegang saham salah satunya dilihat dari tinggi rendahnya nilai perusahaan.

Maksimalisasi nilai perusahaan serta meningkatkan akan pemegang saham serta meningkat kinerja merupakan kewajiban dan tujuan dari perusahaan (Andini, 2014). Dominick 
(2005) menyatakan bahwa tujuan pendirian diperusahaan, karena memaksimalisasi nilai perusahaan yang berarti untuk memaksimalkan kemakmuran akan pemegang saham yang menjadi tujuan utama perusahaan. Sedangkan nilai perusahaan akan harga pasar sahamnya (Wahyudi dan Pawestri, 2006)

Peningkatan nilai perusahaan bisa tercapai jika ada kerja sama antara manajemen perusahaan dengan pihak lain yang meliputi sharehoder maupun stakeholder dalam membuat keputusan-keputusan keuangan dengan tujuan memaksimalkan modal kerja yang dimiliki (Sukirni, 2012).

Menurut Sudiani dan Damayanti (2016), nilai perusahaan adalah harga pasar dari saham perusahaan yang akan terbentuk antara pembeli dan penjual di saat terjadinya transaksi, hal ini dikarenakan harga pasar saham dianggap sebagai cerminan dari nilai aset perusahaan yang sesungguhnya. Sedangkan menurut Keown (2004), nilai perusahaan merupakan nilai pasar atas surat berharga serta modal perusahaan yang beredar. Nilai perusahaan merupakan persepsi investor terhadap tingkat keberhasilan perusahaan yang tercermin pada harga saham, semakin tinggi nilai perusahaan semakin besar kemakmuran yang diterima oleh pemilik saham.

\section{Return Saham}

Menurut Jogiyanto (2014: 19) return merupakan hasil yang bisa dari investasi. Return dapat berupa return realisasikan yang sudah terjadi atau return yang belum terjadi akan tetapi yang diharapkan dimasa yang akan datang. Return realisasian sama dengan return total yang merupakan return kesemua dari investasi dalam suatu periode tertentu. Return saham adalah tingkat keuntungan yang dinikmati oleh pemodal atas suatu investasi yang dilakukannya (Robert Ang, 2001). Dalam teori pasar modal, tingkat pengembalian yang diterima oleh seorang investor dari saham yang diperdagangkan di pasar modal (saham perusahaan go public) biasa diistilahkan dengan return. Menurut Brigham dan Houston (2006), return saham berbanding positif dengan risiko, artinya semakin besar risiko yang ditanggung oleh pemegang saham, maka keuntungan akan semakin besar pula, begitu juga sebaliknya.

Menurut Jogiyanto (2010:205), Return Saham merupakan nilai yang diperoleh sebagai hasil dari aktivitas investasi. Return yang diharapkan berupa deviden untuk investasi saham serta pendapatan bunga untuk investasi di surat utang. Jika expected return suatu saham lebih besar dari required return saham tersebut, maka saham tersebut mengalami undervalued, dan apabila expected return lebih kecil dari required return-nya, maka saham tersebut overvalued (Bodie et al., 2008). Tandelilin (2010:47) mengemukakan bahwa return merupakan salah satu 
faktor yang memotivasi investor berinteraksi dan juga merupakan imbalan atas keberanian investor dalam menanggung risiko atas investasi yang dilakukannya.

\section{METODE PENULISAN}

Metode penulisan Artikel ilmiah ini menggunakan metode kualitatif dan studi literature atau

Library Research. Untuk mengkaji buku-buku literature dengan teori yang akan dibahas khususnya di Lingkup Manajemen Keuangan. Dalam menganalisis artikel ilmiah yang bereputasi serta artikel ilmiah dari jurnal yang belum bereputasi. Keseluruhan artikel ilmiah yang bisa dicitasi bersumber dari Mendeley serta Scholar Google.

Didalam Penelitian kualitatif, kajian pustaka harus bisa digunakan secara konsisten dengan asumsi metodologis. Artinya harus digunakan secara induktif kemudian tidak mengarah di pertanyaan-pertanyaan yang akan diajukan oleh peneliti. Terdapat salah satu alasan untuk melakukan penelitian kualitatif adalah bahwa penelitian bersifat eksploratif (Ali \& Limakrisna, 2013).

Selanjutnya dibahas secara mendalam pada bagian yang berjudul" Pustaka Terkait" (Related Literature) atau Kajian pustaka( "Review of Literature"), sebagai dasar perumusan hipotesis dan selanjutnya akan menjadi dasar untuk melakukan perbandingan dengan hasil atau temuan-temuan yang terungkap dalam penelitian, (Ali \& Limakrisna, 2013).

\section{PEMBAHASAN}

\section{Pengaruh Nilai Perusahaan terhadap Likuiditas}

Dari hasil analisis regresi dapat diketahui bahwa Loan to Deposit Ratio berhubungan positif serta tidak signifikan terhadap Likuiditas. Nilai perusahaan baik akan mempengaruhi likuiditas yang rendah, kondisi ini bisa diartikan bahwa nilai perusahaan meningkat bisa mempengaruhi nilai aktiva lancar (yang bisa dijadikan uang) untuk membandingkan hutang jangka pendek. Perusahaan semakin meningkat karena semakin tinggi likuiditas perusahaan, hal ini menyebabkan tersedianya banyak dana (Anggraini, 2012). Menurut Galtom (2011) bahwa perusahaan mampu untuk memenuhi kewajiban jangka pendeknya sehingga likuiditas yang tinggi memiliki keberartian. Asiri (2015) dalam penelitiannya pada perusahaan-perusahaan yang terdaftar di Bursa Efek London menemukan adanya pengaruh nilai perusahaan terhadap likuiditas.

\section{Pengaruh Return Saham terhadap Likuiditas}


Renturn saham tidak memiliki pengaruh yang signifikan terhadap likuiditas. hal ini bertolak belakang dengan teori yang menyebutkan bahwa likuiditas akan dipengaruhi oleh harga sama. Hal ini terjadi karena investor tidak terlalu memperhatikan perbandingan aktiva dan hutang lancar dari perusahaan. Penyebabnya ialah keyakinan pasar terhadap kemampuan perusahaan dalam membayar kewajiban jangka pendeknya. Selain itu penyebab keyakinan investor, karena kuatnya pondasi keuangan peusahaan sektor Property dan Real Estate, sehingga investor cenderung tidak melihat Likuiditas dalam melakukan investasinya dan pada akhirnya tidak berpengaruh terhadap return saham. Maka menyebabkan hasil penelitian ini tidak signifikan.

\section{Pengaruh Nilai Perusahaan terhadap Suku Bunga}

Hasil pengujian yang dilakukan dengan menggunakan Uji t untuk mengetahui hubungan variabel suku bunga yang signifikan negatif memoderasi profitabilitas terhadap nilai perusahaan. Dengan demikian, maka dalam penelitian ini Ha4 diterima yaitu suku bunga sebagai variabel moderasi memperkuat hubungan antara profitabilitas terhadap nilai perusahaan. Hasil penelitian ini mendukung penelitian Purnomo dan Widyawati (2013) dan Purnomosidi et.al. (2014). Dan tidak mendukung penelitian Amperaningrum dan Agung (2011) dan Jubaedah et. al. (2016).

\section{Pengaruh Return Saham terhadap Suku Bunga}

Return saham berpengaruh positif dan tidak signifikan kepada tingkat suku bunga. Suku bunga menunjukkan pengaruh positif dan tidak signifikan terhadap return saham. Hal ini bertentangan dengan mayoritas teori yang ada dan hipotesis yang diajukan sebelumnya. Suku bunga yang tinggi menyebabkan harga bahan baku menjadi mahal, perusahaan akan memilih alternatif pembiayaan yang lebih murah dan lebih efisien dengan harga jual yang tinggi sehingga tidak akan mempengaruhi profitabilitas perusahaan pada return saham yang akan diterima investor. Suku bunga yang tinggi tidak mempengaruhi investor dalam menentukan investasi pada perusahaan property dan real estate menurut Wismantara (2017) keputusan investasi melibatkan faktor psikologis dari investor itu sendiri sehingga tidak selamanya teori yang ada selalu terbukti. Menurut Dwita, \& Rahmidani (2012) suku bunga meningkat tidak mempengaruhi return saham. Hal ini terjadi karena tingkat suku bunga berdasarkan BI Rate tidak dapat dijadikan parameter dalam mengukur return saham pada perusahaan property dan real estate. 
Hasil penelitian ini sejalan dengan penelitian yang dilakukan oleh Dwita, \& Rahmidani (2012) dalam penelitiannya menyatakan bahwa suku bunga berpengaruh positif dan tidak signifikan terhadap return saham. Serta sejalan dengan penelitian yang dilakukan oleh Kristanto (2016) dalam penelitiannya disebutkan bahwa suku bunga berpengaruh positif dan signifikan terhadap return saham. Namun hasil penelitian ini bertolak belakang dengan penelitian yang dilakukan oleh Saputra \& Dharmadiaksa (2016), dalam penelitiannya disebutkan bahwa suku bunga berpengaruh negatif dan signifikan terhadap return saham.

\section{Pengaruh Likuiditas terhadap Suku Bunga}

Likuiditas memiliki pengaruh positif terhadap suku bunga. Hal ini bisa jelaskan karena kemampuan akan membayar hutang jika tingkat suku bunganya rendah. Sejalan dengan penelitian Sudana (2009:24) likuiditas perusahaan yang bisa diukur dengan rasio lancar (current ratio). Rasio lancar menunjukkan kemampuan perusahaan untuk membayar utang lancar dengan menggunakan aktiva lancar yang dimiliki. Sedangkan Tingkat bunga yang tinggi juga akan meningkatkan biaya modal yang akan ditanggung perusahaan dan juga akan menyebabkan return yang diisyaratkan investor dari suatu investasi akan meningkat (Wismantara, 2017).

\section{Conceptual Framework}

Berdasarkan rumusan masalah penulisan artikel ini dan kajian studi literature review baik dari buku dan artikel yang relevan, maka di perolah rerangka artikel ini seperti di bawah ini.

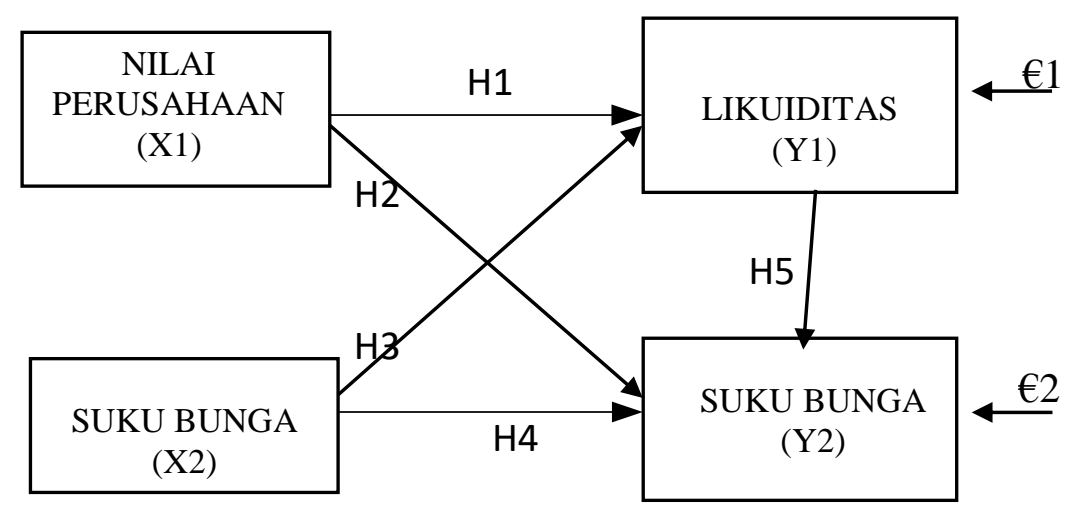

Gambar 1: Rerangka Berpikir

Nilai Perusahaan dan Suku Bunga memiliki hubungan dan berpengaruh terhadap Likuiditas dan Suku Bunga baik secara langsung maupun tidak langsung. 
Selain dari variabel Nilai Perusahaan dan Suku Bunga yang mempengaruhi Likuiditas dan Suku Bunga masih banyak variabel lain yang mempengaruhinya, di antaranya adalah variabel:

1. X3 : Ukuran perusahaan sudah diteliti oleh (Seftianne, 2011), (Sawir, 2004), dan (Barchly dan Smith, 1998)

2. X4 : Kesempatan Bertumbuh sudah diteliti oleh (Santoso, 2011), (Jensen,1986) dan (Fatmawati, 2011).

3. X5 : Perputaran Modal Kerja sudah diteliti oleh (Ahmad, 2002), (Djarwanto, 2004)

\section{KESIMPULAN DAN SARAN}

\section{Kesimpulan}

Berdasarkan rumusan artikel, hasil serta pembahasan, maka bisa di rumuskan hipotesis untuk riset selanjutnya:

1. Nilai perusahaan berpengaruh terhadap likuiditas

2. Return saham berpengaruh terhadap likuiditas

3. Nilai perusahaan berpengaruh terhadap suku bunga

4. Return saham berpengaruh terhadap suku bunga

5. Likuiditas berpengaruh terhadap suku bunga

\section{Saran}

Berdasarkan kesimpulan di atas, maka saran yang artikel ini merupakan bahwa masih banyak factor lain kemudian mempengaruhi likuiditas dan suku bunga, selain dari nilai perusahaan dan return saham pada semua tipe dan level

Berdasarkan Kesimpulan di atas, maka saran pada artikel ini adalah bahwa masih banyak factor lain yang mempengaruhi likuiditas dan suku bunga, selain dari nilai perusahaan dan return saham pada semua tipe dan level organisasi atau perusahaan, oleh karena itu masih di perlukan kajian yang lebih lanjut untuk mencari faktor-faktor lain apa saja yang dapat mempengaruhi likuiditas dan suku bunga selain yang di teliti pada artikel ini.

\section{Bibliography/Daftar Pustaka:}


Adeputra, Munawir dan Wijaya, Indra. (2015). The Effect of Exchange Rates, Net Profit Margin, Return On Assets, Interest Rates, and Inflation on Food and Beverage Stock Returns. Kalbisocio, 2(2): 209 - 216.

Ali, H., Limakrisna. (2013). Research Methods Practical Guidelines for Solving Business Problems, Writing Thesis, Thesis, Dissertation. Jakarta: Universitas Terbuka

Bilal, Ahmad Raza., et al.. (2012). How Terrorism and Macroeconomic Factors Impact on Returns: A Case Study of Karachi Stock Exchange. World Applied Sciences Journal, 19 (11): $1575-1584$.

Bodie, Zvi., et al.. (2008). Investments. Edisi ke-6. Jakarta: Salemba Empat

Buana, Gresna. (2016). The Influence of Market Risk, Exchange Rates, Interest Rates, Trading Volume on Stock Returns (Case studies on companies listed in the LQ45 index). Skripsi Fakultas Ekonomika dan Bisnis Universitas Diponegoro, Semarang.

Butt, Babar Zaheer., Rehman, Kashif Ur., Khan M. Aslam dan Safwan, Nadeem . (2010). Apakah faktor ekonomi mempengaruhi pengembalian saham? Analisis tingkat perusahaan dan industri.. African Journal of Business Management, 4(5): 583-593.

Dewi, N. S., \& Prabowo, R. E. (2018). Product Quality Performance, Price Perception, Promotion, and Lifestyle in Influencing the Isotonic Beverage Purchase Decision Process (Study of Isotonic Beverage Consumers in Semarang City).

Dwita, Vidyarini dan Rahmidani, Rose. (2012). The Influence of Inflation, Interest Rates and Exchange Rates on Stock Returns of the Restaurant, Hotel and Tourism Sector. Jurnal Kajian Manajemen Bisnis, 1(1): 59-72.

Faoriko, Akbar. (2013). The Influence of Inflation, Interest Rates and Rupiah Exchange Rate on Stock Returns on the Indonesia Stock Exchange. Skripsi. Universitas Negeri Yogyakarta.

Fahmi, I. (2016). Human Resource Management Theory and Applications. Bandung: Alfabeta.

Husnan, S., \& Pudjiastuti, E. (2015). Fundamentals of Financial Management, Edisi Ketujuh. Yogyakarta: UPP STIM YKPN.

Hasania, Z. (2016). The Influence of Current Ratio, Company Size, Capital Structure, and ROE on Value of Pharmaceutical Companies Listed on the Indonesia Stock Exchange 20112014. Jurnal Berkala Ilmiah Efisiensi, 16(3).

Jogiyanto, (2014). Portfolio Theory and Investment Analysis (10th Edition).Yogyakarta :BPFE Karim, Abdul. (2015). Analysis of the Influence of Internal and External Factors on the Return of Shares of Manufacturing Companies Listed on the Indonesia Stock Exchange (BEI) 2010-2012. Media Ekonomi dan Manajemen, 30(1): 41-55. 
Kandir, Serkan Yilmaz. (2008). Macroeconomic Variables, Firm Characteristicsand Stock Returns: Evidence from Turkey. International Research Journal of Finance and Economics, 16: 36-44.

Kasmir.(2013). Bank dan Lembaga-Keuangan Lainnya. Ed rev 2008. Jakarta: Raja Grafindo Press

Kristanto, Muhamad Enggal. (2016). Analysis of the Effect of Inflation, Exchange Rates, and Interest Rates on the Joint Movement of Ihsg Stock Returns and Trading Volume for the Period of January 2006 - December 2015. Skripsi Fakultas Ekonomika dan Bisnis Universitas Diponegoro, Semarang.

Khalwaty, T. (2010). Inflation and the Solution. Jakarta: PT Gramedia Pustaka Utama

Mishkin, Frederic S. (2008). Ekonomi Uang, Perbankan, dan Pasar Keuangan. Edisi 8. Jakarta : Salemba Empat.

Mamduh HM. (2004). Manajemen Keuangan. Yogyakarta:BPFE

Margaretha, F. (2011). Manajemen keuangan untuk manajer nonkeuangan. Jakarta: Erlangga. Mariana. (2015). Analisis Rasio Likuiditas, Rasio Solabilitas dan Profitabilitas untuk Menilai Kinerja Keuangan pada PT Maju Daya Bersama. Politeknik Negeri Banjarmasin. Hal 98

Misran, M., \& Chabachib, M. (2017). Analysis of the Effect of Der Cr and Tato on Pbv with Roa as an Intervening Variable (Studies in Property and Real Estate Companies Registered in Bei 2011-2014). Diponegoro Journal Of Management, 6(1), 203-215.

Mardiyati, U., \& Rosalina, A. (2013). Analysis of the effect of exchange rates, interest rates and inflation on the stock price index of a case study of property companies listed on the Indonesian stock exchange. JRMSI-Jurnal Riset Manajemen Sains Indonesia, 4(1), 1-15.

Noerirawan, M. R., \& Muid, A. (2012). Pengaruh faktor internal dan eksternal perusahaan terhadap nilai perusahaan (studi empiris pada perusahaan manufaktur yang terdaftar di Bursa Efek Indonesia periode 2007-2010). Diponegoro Journal of Accounting, 1(1), 582-593.

Purnomo, Tri, Hendra dan Nurul Widyawati. (2013). "Pengaruh Nilai Tukar, Suku Bunga, dan Inflasi terhadap Return Saham pada Perusahaan Properti di Bursa Efek Indonesia”, Jurnal Ilmu \& Riset Manajemen, Volume 2 Nomor 10.

Puspitaningtyas, Z. (2015). Prediksi Risiko Investasi Saham. Pandiva Buku.

Rahwidhiyasa, D. (2013). Pengaruh Inflasi, Tingkat Suku Bunga SBI, Earning Per Share, Price Earning Ratio dan Price Book Value terhadap Harga Saham. Jurnal Ilmu Manajemen (JIM), 1(4). 
Sawir, A. (2004). Kebijakan Pendanaan dan Restrukturisasi Perusahaan. Jakarta: PT. Gramedia Pustaka Utama.

Santoso, Y. A. (2011). Analisis Faktor yang Mempengaruhi Likuiditas Pada perusahaan Manufaktur yang Listed di Bursa Efek Indonesia (BEI) Periode 2007-2009.

Seftianne. (2011). Faktor-faktor Yang Mempengaruhi Struktur Modal Pada Perusahaan Publik Sektor Manufaktur. Jurnal Bisnis dan Akuntansi Vol. 13 , 39-56.

Sudana, I. M. (2009), Manajemen Keuangan Teori dan Praktek. Airlangga University Pers, Surabaya.

Sunariyah. (2013). Pengantar Pengetahuan Pasar Modal (Edisi 6). Yogyakarta : UPP STIM YKPN.

Sugiono, A., \& Untung, E. (2016). Panduan praktis dasar analisa laporan keuangan. Jakarta: Grasindo

Siddik, M. H., \& Chabachib, M. (2017). Pengaruh ROE, CR, Size, Dan Kepemilikan Institusional Terhadap Nilai Perusahaan Dengan Struktur Modal Sebagai Variabel Intervening. Diponegoro Journal of Management, 6(4), 608-622.

Titman, Sheridan,Keown AJ, MartinJD. (2014). Financial Management Principles and Applications, Ed ke-12. Edinburgh: Pearson

Warrad, L. (2014). Pengaruh Rasio Saat Ini pada Marjin Laba Bersih Sektor Real Estat Yordania.European Journal of Economic, Finance and Administrative Sciences. Issued, 63. 